\title{
SCOTLAND FOR FRANCO: CHARLES SAROLÉA $V$. THE RED DUCHESS
}

\author{
GAVIN BOWD
}

Daniel Gray's recent book and TV series, Homage to Caledonia, have confirmed the image that many have of Scotland and the Spanish Civil War: the uplifting story of a relatively large number of deeply committed and courageous Scots who volunteered to fight for democracy and socialism against General Franco and his fascist allies. ${ }^{1}$ Here, I do not wish to deny or denigrate such commitment: some 549 Scots volunteered to fight for the Republic, but we know of only one Scot, a Seaforth Highlander from the Black Isle, who ended up fighting in Franco's Moorish regulares. ${ }^{2}$ Nevertheless, more light remains to be shed on the small, yet still vocal, minority in Scotland who chose to support the Nationalist side. Gray's brief chapter on 'Scots for Franco' does not draw on archival sources or recent secondary literature. What is more, his book passes over the crucial, albeit not universal, connection between religious background and Scottish attitudes to Spain. This article focuses on redressing some of these serious omissions by exploring the case of pro-fascist Professor Charles Saroléa and his campaign against the duchess of Atholl, a prominent supporter of the Republic. The case of Saroléa offers insights into the network of Francoist sympathisers in Scotland and the limits of their influence in a country deeply divided on religious lines. The antiBolshevik professor's intervention in the debate on Spain is also considered here in relation to appeasement and the ultimate fate of fascism.

Charles Saroléa was born in Belgium in 1870 and went on to study philology at various European universities. In 1894, he became the first lecturer in French at Edinburgh University and, in 1918, its first professor. Between 1901 and 1953, he was consul for Belgium in Scotland, although, in 1920, he adopted British nationality. Saroléa claimed to know more than twenty languages. His huge apartment at 21-2 Royal Terrace held a private library of over 200,000 volumes: the largest, he claimed, in the British Empire. He was editor of Everyman,

1 D. Gray, Homage to Caledonia (Edinburgh, 2008).

2 See S. M. Cullen, 'The Fasces and the Saltire: The Failure of the British Union of Fascists in Scotland, 1932-1940', Scottish Historical Review, 87 (2008), pp. 306-31.

Journal of Scottish Historical Studies 31.2, 2011, 195-219

DOI: $10.3366 /$ jshs.2011.0021

(C) Edinburgh University Press 2011 
a journal devoted to international understanding which promoted the 'third way' economic doctrine of distributism. An avowed cosmopolitan, Saroléa was in favour of European co-operation and the prevention of war at all costs. With the outbreak of the Great War, he was a vocal opponent of Prussianism, militarism and the Lutheran church: in 1915, he published The Curse of the Hohenzollern. ${ }^{3}$ Paradoxically, he defended small nations against aggression rooted in the principle of nationalities. ${ }^{4} \mathrm{He}$ was an active propagandist for Belgium and made a long speaking tour of the United States. He promoted the cause of Czech and Slovak independence and struck up an acquaintance with Edvard Benes and Tomas Masaryk. ${ }^{5}$ He was also a vocal supporter of Poland. But, as his biographer Sam Johnson points out, at the apex of Saroléa's affections stood Imperial Russia, a state he long regarded as his spiritual home: 'the only state capable of safeguarding Europe's spiritual integrity ${ }^{6}$. In 1916, he published Europe's Debt to Russia. ${ }^{7}$

Sarolea welcomed the defeat of the Kaiser and the liberation of Belgium, but he denounced the injustices of the Versailles diktat, which, in his view, only reinvigorated national rivalries and prepared the way for German revenge. After October 1917, the professor was convinced that the foundations of civilisation faced an even greater threat from communism than they did from a Prussianised Europe. A visit to the land of Lenin only confirmed his worst fears. In Impressions of Soviet Russia (1924), this devout catholic denounced 'The Kingdom of the AntiChrist ${ }^{.}{ }^{8}$ During the inter-war period, Saroléa would write regularly to The Times, and The Scotsman, in particular, denouncing the Bolshevik threat and supporting those radical right-wing regimes and movements ready to stand up to it. ${ }^{9}$

In 1931, Saroléa resigned from Edinburgh University in protest at what he considered to be the lamentable decline in pedagogical and human standards in the Scottish university system as a whole. ${ }^{10} \mathrm{He}$ would now exploit his apparently inexhaustible energy, wealth and contacts to the geopolitical struggles of the 1930s, establishing very friendly relations with the authorities in Rome and Berlin. For example, in the mid-1930s, Saroléa supported Mussolini's invasion of Abyssinia. In a pamphlet, 'The Case against Sanctions', and a series of letters, he attacked the League of Nations as an instrument of war. His work in the Scottish press was deeply appreciated by the Italian ambassador, Dino Grandi, and, in February 1936, he was guest of honour at a dinner hosted by the Fascio di Edinburgo.

3 C. Saroléa, The Curse of the Hohenzollern (London, 1915).

4 See C. Saroléa, 'Via Pacis', Everyman, 5 Jan. 1917, p. 223.

5 See D. Hajkova, 'T. G. Masaryk a Charles Sarolea. Ceskoslovenska propaganda v Anglii 1915-1917', Historie a vojenstvi (June 1998), pp. 35-57.

6 S. Johnson, 'Playing the Pharisee? Charles Saroléa, Czechoslovakia and the Road to Munich, 1915-1939', The Slavonic and East European Review, 82, 2 (2004), p. 296.

7 C. Saroléa, Europe's Debt to Russia (London, 1916).

8 C. Saroléa, Impressions of Soviet Russia (London, 1924). 'The Kingdom of the Anti-Christ' is the title of chapter 6

9 See Johnson, 'Playing the Pharisee?'.

10 The Scotsman, 13 Oct. 1934. 
Around this time, Saroléa began a rich correspondence with Lady MarieLouise Maxwell-Scott, wife of General Sir Walter Maxwell-Scott, great-grandson of the novelist Sir Walter Scott. ${ }^{11}$ American by birth, Lady Maxwell-Scott had spent much of her life in Europe. Her first husband had been French, which contributed to her keen interest in continental affairs. Her second husband had a vast array of political and personal connections which included the British Ambassador to Rome, Sir Eric Drummond. Lady Maxwell-Scott seems to have been dazzled by Saroléa's cosmopolitan intellect, and adhered wholeheartedly to his bracing views on Abyssinia and the failure of the League of Nations. ${ }^{12}$ In a letter to her on 21 January 1936, he wrote:

I have embarked on a campaign which is bearing good fruit. And curiously enough, in that campaign I have some of my best fellow workers in the Conservative Party. I also find that ladies are most efficient propagandists and liaison officers. One very influential Conservative lady politician, the Duchess of Atholl, is in daily contact with me. ${ }^{13}$

Indeed, it was on the advice of Lady Maxwell-Scott that the professor sent to the duchess of Atholl his critical examination of the Covenant of the League of Nations. In his covering letter of 6 January 1936, he wrote to 'my dear Duchess': 'If you ever happen to be in Edinburgh I would be delighted to discuss these matters with you. I would always be delighted to put you up and you would see the largest private Library in the British Empire-some 250,000 volumes, filling 26 rooms'. ${ }^{14}$ On 16 January, the duchess replied: 'I shall send it to those Conservative MPs who I believe see things as I do because I feel the letter gives most useful information which very few of us have got', although his criticism of the allocation of mandates, 'will, I fear, play into the hands of those who wish to restore the German Colonies ${ }^{15}$. The duchess sent copies of his Scotsman letters of 8-9 January to 180 MPs, half of the Conservative group. On 17 January, Saroléa wrote appreciatively:

I hope you will not relax in your efforts to fight the policy of sanctions with true Scottish and Highland determination. And please do not forget that just as in this country the driving force behind the policy of sanctions is the hatred of Fascism and the propaganda of the Trade Unions. Even so the driving forces

${ }^{11}$ For the correspondence between Saroléa and Lady Maxwell-Scott see Edinburgh University Library, Special Collections [hereafter EUL], Saroléa Collection, 64. Dates of correspondence from this collection appear in the text of this article wherever possible; where this has not been possible they are cited in the notes.

12 See, for example, EUL, Saroléa Collection, 64, Lady Maxwell-Scott to Charles Saroléa, 9 Jan. 1936.

13 EUL, Saroléa Collection, 88

14 EUL, Saroléa Collection, 60

15 EUL, Saroléa Collection, 60 
at Geneva behind sanctions is Comrade Litvinoff and Bolshevik Russia. It was an evil day when Germany left the League, but it was a worse day when the Soviet entered it. ${ }^{16}$

On 24 January, the duchess let him know that "when I was in the House yesterday, several Members to whom I had sent your letter of January 9th came up and thanked me warmly for it'. ${ }^{17}$ That said, even Lady Maxwell-Scott expressed private doubts on the efficacy of Saroléa's interventions. On 26 January she wrote to Paul Morand, the French writer-diplomat and future Vichy ambassador to Bucharest:

I am very frightened by this English affection for the League of Nations, which will end in driving Italy out of it, if not into the arms of Germany. Can you not begin preaching the reform of the League? We must get something started, we who believe that Italy is useful to us in Europe [...] They live on the Moon these dear English, and would not recognise Europe if they met her. You can do so much because you do it lightly. I can send you learned works by a Professor of the University of Edinburgh but no-one will read him. But his idea is the right one, and could be put otherwise. ${ }^{18}$

It is unsurprising that Sarolea found common ground with Katharine StewartMurray, duchess of Atholl. From 1923 the duchess was Conservative MP for Kinross and West Perthshire. She was well known for her campaigns against slave labour in the Soviet Union, most notably with her 1931 book The Conscription of a People. ${ }^{19}$ She was also alarmed by anti-clerical violence in Spain. For example, on 11 January 1933, she wrote on this subject to her friend the earl of Glasgow, a Scottish fascist sympathiser:

I feel it would be rather inconsistent if our Movement said nothing about what had happened in Spain though fortunately there the Communists do not seem to be actually in power. The Government, however, appears to have taken a very weak line about this burning of churches, in that they have allowed them to take place. [...] I should, therefore, like to feel that we could talk about what is happening in Spain as an indication of what Communists do all the world over if they are given the chance but I should suggest that it be not too much emphasised for fear that we should be regarded as too much identified with the Roman Catholics. ${ }^{20}$

16 EUL, Saroléa Collection, 60.

17 EUL, Saroléa Collection, 60.

18 Archives of the Institut de France, Paris, Morand Papers, 2 AP 7.

19 K. Atholl, The Conscription of a People (London, 1931).

20 Blair Castle Archives [hereafter BCA], Duchess of Atholl Papers, 44/7. 
The duchess confirmed her right-wing credentials by repudiating, in 1935, the National Government whip in protest against the India Bill, which prepared the way for that country's independence. She was also initially opposed to confronting Mussolini and receptive to Saroléa's robust critique of the League of Nations. ${ }^{21}$

However, in the course of 1936, the duchess moved towards a position of antiappeasement which would strain to breaking-point her relations with her local Conservative Association as well as occasional allies such as Charles Saroléa. After the remilitarisation of the Rhineland in March 1936, Nazi Germany replaced the Soviet Union as what the duchess considered to be the main threat to British interests. On 19 May 1936, after close study of an unexpurgated version of Mein Kampf, she wrote to Stanley Baldwin that 'Germany is the only serious danger to peace in Europe'. ${ }^{22}$ On 6 August 1936, the duchess wrote to Saroléa:

Surely liberty is so precious that we must be ready to fight for it if we cannot preserve it otherwise? It is inconceivable to think that our people would submit to living under Nazi rule if they had any idea of what it meant. And if liberty can be preserved, civilisation need not be destroyed as people are so ready to say, surely so long as there is liberty, the human mind can restore civilisation, but if liberty goes, everything goes? ? $^{23}$

In his last existing letter to the duchess, on 17 August, the professor expressed his concern at the content of her letters to The Scotsman, Daily Telegraph and Morning Post: 'You are treading on very dangerous ground and you are expounding views which are not only dangerous, but which I think to be erroneous [...] You do an injustice to the Soviet government in comparing their propaganda to that of the Nazis. The Moscow propagandists are incomparably the greater artists'. ${ }^{24}$

The outbreak of the Spanish Civil War in July 1936, and the involvement of Nazi Germany and fascist Italy, confirmed the duchess's views on the threat to peace in Europe. At first, her involvement was humanitarian-concerned mainly with the plight of refugees - and in the autumn she joined the All-Party Committee for Spanish Relief. Early in 1937, she made a tour of Republican Spain, surveying the havoc caused amongst the civilian population by Luftwaffe bombing. This visit led her to criticise the one-sided effect of the Anglo-French policy of 'non-intervention' in the conflict. As Stuart Ball points out, 'her concern thus evolved from the charitable to the political, and from the particular case of Spain to the wider issue of the appeasement of dictators in general'. ${ }^{25}$

\footnotetext{
21 See S. Ball, 'The Politics of Appeasement: the Fall of the Duchess of Atholl and the Kinross and West Perth By-election, December 1938', Scottish Historical Review, 69 (1990), pp. 49-83.

22 BCA, Duchess of Atholl Papers, 22/4

23 EUL, Saroléa Collection, 60.

24 EUL, Saroléa Collection, 60.

25 Ball, 'The Politics of Appeasement', p. 56.
} 
Her pro-republican sympathies earned Katharine Stewart-Murray the sobriquet of 'red duchess' and outraged erstwhile friends. On 23 June 1937, Arnold Lunn, a pioneer of alpine skiing who had just reported from 'white' Spain for The Tablet, reproached her for accepting 'the hospitality of the persecutors of the Catholic Church'. ${ }^{26}$ She also attracted the ire of fellow Conservative MP, Captain Archibald Maule Ramsay, who wrote on 6 September 1937:

You are espousing the cause of the Reds in Spain. The Communists, and other homicidal extremists in the 'Government' (which does not govern), are a small fraction as the Socialists are in our National Government, - BUT whereas our Socialist fraction keeps its proper place-in Spain the Red minority seized the whole machine by murder and terrorism. ${ }^{27}$

Ramsay failed to convince the duke of Atholl to join his United Christian Front Committee, 'formed to co-operate with the Roman Catholic Church to present a United Christian Front against the Red Menace to Christianity'. ${ }^{28}$ On 4 October, the duchess rebutted Ramsay's version of events in 'red' Spain:

My opinion is that it was Anarchists far more than Communists who were responsible for the violent acts committed on the Government side in the early days and if you know anything of the Anarchist creed you will know that it is diametrically opposed to the Communist one and that Anarchists can therefore never be under the domination of Moscow which I know is what the word 'red' is intended to convey. ${ }^{29}$

On 10 November 1937, Ramsay wrote to the duchess:

I fear there is little use in my discussing any of these subjects with you as I regard all your sources of information as tainted, and the foreigners to whom you look for information, as the scum of Europe. [...] As long as you run with that pack, I fear there is so great a gulf between us that you are not likely to listen to my advice and I am certainly not likely to listen to you. ${ }^{30}$

In her last letter to Ramsay, on 12 November, she asked: 'Can you not see that a new and much more immediate danger has arisen to threaten the peace of Europe than the days when you were sitting under my Chairmanship on the Russian Trade Sub-Committee'. ${ }^{31}$

26 BCA, Duchess of Atholl Papers, 44/3.

27 BCA, Duchess of Atholl Papers, 44/9.

28 BCA, Duchess of Atholl Papers, 44/9, Captain Archibald Ramsay to duke of Atholl, 21 Sep. 1937

29 BCA, Duchess of Atholl Papers, 44/9.

30 BCA, Duchess of Atholl Papers, 44/9.

31 BCA, Duchess of Atholl Papers, 44/9. 
The 'red duchess' also came up against the opposition of the Friends of National Spain (FNS), an association formed under the leadership of Lord Phillimore to 'combat the flood of propaganda emanating from Valencia and Moscow'. ${ }^{32}$ On 6 May 1937, a nationalist representative in London, Alfonso de Olano, informed Jacobo Fitz-James Stuart, the duke of Berwick and Alba, then residing in Seville, that this grouping of businessmen, journalists and peers of the realm would provide 'rapid and effective information to counter Red propaganda, which becomes more and more tendentious and calumnous with each passing day'. ${ }^{33}$ De Olano urged querido Jimmy to join this battle for British minds 'as soon as possible'. ${ }^{34}$

In its founding statement, signed by, among others, the travel mogul Sir Henry Lunn and Conservative MPs Sir Nairne Stewart Sandeman and Henry Page Croft, the FNS declared:

Every cause for which Englishmen of all classes and all creeds have fought in the past-liberty of conscience, the sanctity of human life, the maintenance of public order, and the freedom of lawful trade-are being fought for in Spain by the armies of the Nationalist forces. [...] The conditions of normal and decent life disappeared in July 1936 and no effort has been made to restore them. ${ }^{35}$

In a letter to Croft, the duchess refuted their claims:

I can only say that in April I was in Valencia, Madrid and Barcelona, and that though in the first streets and hotels were crowded and on account of the many refugees who had poured in from the insurgent territory, and in the second selling was pretty continuous, prefect order prevailed in all three towns without any display of force. ${ }^{36}$

The protestant churches in government territory, she claimed, had not been interfered with and many masses were now being said daily in the three principal towns. Franco's advance was thanks to the help of Moors, Foreign Legionaries, and Italian and German aeroplanes. She contrasted this with the robust health of republican territory: around Valencia there were healthy harvests and the steady production of munitions. In conclusion, she pointed to the dangers posed by Nationalist guns at the gates of Gibraltar, and the occupation of Majorca: 'Are these the acts of a friend? Those who ignore them, as do the signatories of the

32 BCA, Duchess of Atholl Papers, 44/5.

33 Archivo de la Administracion, Alcalá de Henares, 54/7198.

34 Archivo de la Administracion, Alcalá de Henares, 54/7198.

35 BCA, Duchess of Atholl Papers, 44/5.

36 BCA, Duchess of Atholl Papers, 44/5. 
letter may indeed be the Friends of National Spain, but are they quite acting as the Friends of Britain?'37

Her vocal support for the Spanish Republic would also trigger a fierce feud with Saroléa. The professor had supported the Spanish Nationalist cause from the outset. In January 1937, he organised a meeting of 150 people at his house for Eleonora Tennant, Scottish pro-Franco author of Spanish Journey. ${ }^{38}$ He then lent his support to the Scottish branch of the FNS, whose Honorary President was Lady Maxwell-Scott. In early 1937, Saroléa made a tour of Nationalist Spain, falling seriously ill in Algeciras. But such misfortune did not shake his convictions.

Saroléa's sympathies were by now explicitly pro-fascist. In August 1937, he attended the Nuremburg rally and was introduced to Adolf Hitler. ${ }^{39}$ On his return to Edinburgh, he gave a series of lectures on the new Germany. One of them, entitled 'The Scottish Origins of the Nazi Religion', was hosted by the Edinburgh University Nationalist Society. Professor Saroléa told his audience:

The philosophy of Nazism, the theory of the dictatorial state, was discovered and formulated a hundred years ago by the greatest Scotsman of his time, namely Carlyle. Subsequently, it was elaborated and developed by another famous Scotsman, the descendant of an illustrious line of Scottish forebears, namely Houston Stewart Chamberlain. There was not one of the doctrines on which the Nazi religion has been built up which was not found either in Carlyle or in Chamberlain. ${ }^{40}$

Ideas of enlightened despotism and aristocratic race, he claimed, had roots in the Scottish genius. However, the Saroléa papers also indicate that these lectures were 'boycotted' by much of the Scottish press. ${ }^{41}$

In January 1938, it was the turn of the Maxwell-Scotts to visit behind the Francoist lines. Lady Maxwell-Scott sent Saroléa this postcard from The Rock Hotel, Gibraltar: 'It is simply heavenly here. Bright warm sun. We start for Seville on Friday and I'll write you later on. If you kept a clipping of any of the Red Lady's speeches do save them for me until I come back'. ${ }^{42}$ Pro-fascist activity continued unabated. Back in Edinburgh, Saroléa played host to Douglas Chandler, Nazi American correspondent of the National Geographic and crusader against the 'Asiatic-Termite-Danger'. ${ }^{43}$ In March 1938, Saroléa was back in the Third Reich. But, as the postcard from Gibraltar indicated, the declarations of 'Red Kitty' were keenly followed by her former friends. After all, her noisy activism

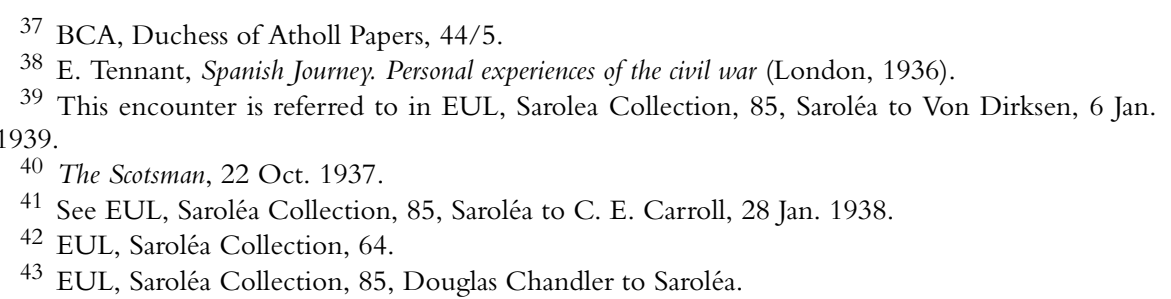


had continued that summer with the publication of her short book, Searchlight on Spain, a Penguin Special dedicated 'to all those Spaniards who are fighting or toiling for national independence and democratic government against tremendous odds' ${ }^{44}$ The book dealt with the extreme poverty and intransigence of the ruling classes which had led to the Popular Front's electoral victory. It then demolished Francoist propaganda about the beginning of the rebellion and the conduct of the war: the coup had, she argued, been planned since 1934 with the connivance of Hitler and Mussolini. The duchess concluded by describing the threat posed by a Francoist victory to Britain's strategic interests, and demanded that the Spanish government should be able to buy arms to defend itself. ${ }^{45}$ The book was an immediate bestseller: the three editions sold over 300,000 copies. It was also translated into French, German and Spanish. This publishing sensation incensed the Francoists. On 23 July 1938, Arnold Lunn wrote to the duchess of Atholl, denouncing the 'inaccuracies' in her account of the Spanish situation:

It will be difficult to reach all those who have read your sixpenny book, but you owe it to your Father, whose prestige you have attempted to exploit for propaganda purposes, to make public amends for these breaches of a code which historians respect and which propagandists too often defy. ${ }^{46}$

The Scots for Franco joined the propaganda war with varying success. On 7 April 1938, the FNS held a meeting at the St Andrews Hall, Glasgow, on the theme 'The Truth About Spain! The Truth About Intervention!' ${ }^{47}$ The Socialist Group on Glasgow Town Council had been bitterly split over letting out the hall to the FNS. On 21 March, Bailie Thomas Kerr, Labour representative for Fairfield, had moved that the hall not be let, arguing that 'the point you are considering is whether or not you are going to give an opportunity to an association who are avowedly out to justify the brutalisation of Franco in Spain, his butchery of the non-combatant population-a man whose hands are reeking with the blood of innocent women and children'. ${ }^{48}$ The opposition to Kerr's motion showed that the left-right dividing line when it came to Spain could become blurred. Among his fiercest opponents was Bailie Alexander McGregor, Labour representative for Exchange and father of the Scottish treasurer of the FNS. He declared: 'If I did not believe that Franco was a democrat I would not be supporting him.' There were then several outraged and angry interjections, including 'he is a murderer' and 'baby-killer'. ${ }^{49}$ The meeting was eventually authorised in the name of freedom of speech: among those approving of the meeting was the prominent catholic and Labour supporter, Patrick Dollan. 1,500 people packed St Andrews

44 K. Atholl, Searchlight on Spain (Harmondsworth, 1937), p. vii.

45 See chapter 13, 'What it Means to Us', of Searchlight on Spain, pp. 299-344.

46 EUL, Saroléa Collection, 60.

47 As advertised by the FNS in the Glasgow Observer, 26 Mar. 1938.

48 Archives of the Archdiocese of Glasgow, CU 12.

49 Archives of the Archdiocese of Glasgow, CU 12. 
Hall to hear Arnold Lunn. He was confronted with continuous interruptions, clenched fists and attempts at singing the Internationale, the anthem of socialism and communism.

The FNS could therefore attract a crowd, but not necessarily a supportive and friendly one. On 12 May, the FNS took the battle to Perth, with a well-attended meeting organised by Captain Luttman-Johnson. James Barrie, a journalist from The Courier, sent the duke of Atholl an account of this meeting, from which come the following quotations. The first to speak was Sir Nairne Stewart Sandeman MP:

They used to hear-and still heard - a great deal about Nero and his murders, etc. He had made a very careful investigation and had discovered that Nero certainly had not murdered more than 500-there were many more savage persons in the world than Nero had been.

A voice: What about the priests of the Spanish inquisition?

Yes or the way they did things in Russia. They murdered them there in tens of thousands and very little was said about it.

When challenged on civilian victims of the bombing of Guernica, Stewart Sandeman retorted that they had been killed by land-mines left by retreating reds. As for the drama of refugees: 'He had been talking to a holy father in London about some of the Basque children and the holy father had told him that everyone of the nurses was frightened because they had broken every window in the place'.

The next speaker was Sir Walter Maxwell-Scott, who began be saying that 'he and General Franco had attended a senior officer's course at Versailles some years ago. He never thought that in those three weeks that he associated with Franco that a civil war would come and that General Franco would take a leading part'. He then referred to a three-week visit he had paid to the warfront in Spain: 'He had had a very good time. He simply went where he wanted. [...] What prevented him getting to Madrid was the arrival of the first International Brigade-15000 splendid men from all over Europe'. In Spanish Morocco, Maxwell-Scott had found that 'Franco was adored by the Moors and that they called him the Holy Man'. As for accusations of Moorish atrocities, he said: 'Possibly Moors liked a bit of loot. He had also known British soldiers who liked a bit of loot'. There was, he argued, 'no colours bar in Spain': the use of Moorish troops against the Republic was akin to 'the Welsh coming to the aid of Northern England against the South of England'. Nevertheless, hecklers demanded answers on Francoist atrocities:

The interruptions continued for nearly five minutes at the end of which the speaker lost his temper and referred to his hecklers at the back of the hall as 'scum'. There was another outcry and one black-shirted member of the audience advanced towards the platform asking for an apology. 
Maxwell-Scott apologised for his language and finished his intervention soon afterwards.

The last speaker was Arthur Loveday, former president of the British Chamber of Commerce in Spain. He explained to his audience that 'in 1931 there began in Spain a revolution organised for years by the efficient and careful work of the Comintern of Russia. This Revolution had been aided very much by the organisation called the Oriental Freemasonry of Spain [...] In 1936 the people of Spain rose in a counter-revolution led fortunately by general Franco'. Loveday recounted his own trip to Spain: 'He had also travelled by air for many hundreds of miles. Why? Because the roads were not safe. Soldiers were holding up tourists and relieving them of their cash and valuables. Wherever he looked he saw the sickle and the hammer (cheers)'. According to Loveday, Franco's war was against those whose only religion was the principles of Karl Marx and class warfare. The reds, he said, had confiscated British property, which provoked shouts of 'whose money? And serve them right!'. 'You have no compassion' responded Loveday. 'You fill me with disgust'. After a number of questions had been asked, a resolution approving of the views of the Association was passed by a majority. ${ }^{50}$ This meeting showed that, while the FNS met organised hostility, they were not a negligible force.

On 17 June 1938, three arrests followed a meeting at the Usher Hall in Edinburgh. According to The Scotsman, it attracted six hundred people including several opponents: 'A large number of stewards, who wore red and yellow badges - the Nationalist colours - were in attendance and these pounced upon the interruptors and ejected the most persistent of them'. One of the speakers, Sir Henry Lunn, declared: 'Would to God we had a Gladstone today to rouse the nation to the enormity of what had happened in Spain. Nero's persecution was a light thing compared with what had happened there'. Dr Denzil Batchelor, a journalist just back from Spain, remarked on the destroyed churches and disappeared nuns and priests in Red territory. He refuted accusations of massacres in Franco territory. At the end of the meeting, one Commandant Mary Allen, in police uniform, moved a resolution supporting 'Franco and the Spanish people' that was carried with only twenty hands held up for the contrary. Meanwhile, at the Mound, the Labour Party and Trades Council had organised an assembly against the supporters of Spanish Fascist brutality. There was also a communist procession outside the Usher Hall: demonstrators carried placards reading 'Franco, Hitler, Mussolini: enemies of religion'. This procession linked up with the Mound protestors to form a crowd of eight hundred..$^{51}$

Such events pointed to the numerical superiority, as well as the aggression, of Republican supporters in Scotland. On 24 July 1937, the Republic's London ambassador had reported to Valencia that 'the only individual, according to all

50 BCA, Duchess of Atholl Papers, 22/18.

51 The Scotsman, 18 Jun. 1938. 
my information, who behaves in Glasgow like a true adversary of the Republican Regime is called Rafael Jorro': Scotland was seen as one of the Republic's securest bastions of support. ${ }^{52}$ During this period, the FNS recognised the influence of the duchess and maintained contact with her, via the duke of Alba, now senior Nationalist representative to London, on the issue of the repatriation of Spanish children, notably to the Basque country. ${ }^{53}$ Nevertheless, the iconic 'red duchess' was a woman that the FNS had to stop. On 19 June 1938, Lady Maxwell-Scott exerted her 'friendly tyranny' on Saroléa: 'Last year you said you would show up the Red Duchess and that she would lose nothing by waiting. Please do it at once. Her book is a filthy collection of red propaganda'. ${ }^{54}$ Saroléa concurred: 'I think the book of the Duchess of Atholl is very important and will do infinite mischief' ${ }^{55} \mathrm{He}$ informed one O'Neill of the press office of the Nationalist legation in Victory House, London: 'I have started at once my answer to our Scottish Tory Bolshevik and I have interrupted a book on Czechoslovakia which I am trying to finish,. ${ }^{56}$ In July 1938, he wrote of the duchess of Atholl and Searchlight on Spain:

That book is all the more mischievous and dangerous because instead of being published at the usual price of 10/6, she has published it in a Bolshevik series at the price of $6 \mathrm{~d}$ which is being circulated in hundreds of thousands of copies. [...] I shall try to have my book published as soon as possible as, in the meantime, the Red Duchess is doing an enormous amount of harm. She has also been addressing Mass Meetings in London, in Paris and in Madrid. Indeed, it seems to me that the dear Scottish Duchess is completely losing her balance of mind [...] Alas! The anti-Franco propaganda in Great Britain is terrifyingly active and efficient, whereas the pro-Franco propaganda is lamentably inefficient. ${ }^{57}$

In September he wrote: 'I hope that my book will help to get "Red Kitty" unseated'. ${ }^{8}$ Saroléa's chance would come with the Munich crisis and Franco-British appeasement of Hitler's demand for the Sudeten Germans of Czechoslovakia to join the Reich.

Since the outbreak of the Spanish Civil War, the duchess of Atholl's relations with local conservatism had deteriorated dramatically. On 1 May 1937, the Association secretary, James Paton, had written to her: 'You have had, I am sure, a very interesting time in Spain, sometimes rather exciting and performed a very humane duty. Unfortunately, I hear rumours of very strong objections from

52 Archivo de la Administracion, Alcalá de Henares, 54/7206.

53 Archivo de la Administracion, Alcalá de Henares, 54/7247.

54 EUL, Saroléa Collection, 60.

55 EUL, Saroléa Collection, 60.

56 EUL, Saroléa Collection, 86.

57 EUL, Saroléa Collection, 86.

58 EUL, Saroléa Collection, 86. 
constituents'. ${ }^{59}$ The duchess replied that 'I think public opinion down here is turning a good deal since the destruction of Guernica', although she did make some acknowledgment of the opposition: 'You have to remember that Catholics are strongly against the Spanish Government. Is opposition coming from any other quarter? ${ }^{60}$ Paton informed her that powerful opponents were Colonel Rupert Dawson, a Roman Catholic, who was 'very bitter' about her letter in the Glasgow Evening News. Another grandee, Sir Kay Muir, was 'a strong supporter of the Insurgents in Spain, as he says he would rather have Spain under a Hitler or Mussolini than under Communistic rule. [...] I would humbly request you to restrict your activities and support of the Spanish Government meantime'.

Indeed, her views on Spain had alienated the Roman Catholics in the Association who were receptive to Francoist propaganda, notably executive member Dawson. Dawson was helped in his oppositional efforts by the archbishop of Edinburgh and John Campbell, secretary of the Catholic Union, who played an active role in distributing pro-Franco propaganda published by the Spanish Press Service. ${ }^{61}$ Indeed, as Tom Gallagher has shown, the catholic church in Scotland was active in support of Franco: The Glasgow Observer and Catholic Herald was an unquestioning mouthpiece for Nationalist propaganda, while, at the shrine of Carfin, near Motherwell, up to seventy thousand people attended masses of reparation for the crimes committed against the church in Spain. ${ }^{62}$ On 1 June 1937, the archbishop asked Campbell to provide Dawson with information on the civil war: 'He certainly will have sufficient ammunition to make an impression on the Red battalions. Whether he will be able to use the information with sufficient skill to silence the unbalanced Duchess in Perthshire remains to be seen' ${ }^{63}$ This information was used for a pamphlet rebutting her Impressions of Spain. ${ }^{64}$ On 26 June, Campbell congratulated Dawson: 'I think your publication has served a very useful purpose and, so far as I can see, the Duchess of Atholl and other kindred spirits have a monopoly of Press and platform so far as Spain is concerned'. ${ }^{65}$ However, opposition to the duchess's foreign policy stance went beyond catholic circles to include the anti-Bolshevik right. What is more, writes Stuart Ball, 'her identification with foreign affairs, her overseas missions, and her political and social sojourns in London had the effect of eroding her local links, so that in some eyes she took on the appearance of an outsider, careless of local interests and indifferent to the concerns of the parish pump ${ }^{6}{ }^{66}$

59 BCA, Duchess of Atholl Papers, 22/18.

60 BCA, Duchess of Atholl Papers, 22/18, Duchess of Atholl to James Paton, 4 May 1937.

${ }^{61}$ See the John Campbell Papers at the Archives of the Archdiocese of Glasgow, CU 12.

62 T. Gallagher, Glasgow's Uneasy Peace: Religious Tension in Modern Scotland (Manchester, 1987), pp. 206-7.

63 Archives of the Archdiocese of Glasgow, CU 12.

${ }^{64}$ BCA, Duchess of Atholl Papers, 22/6, copy of K. Atholl, Impressions of Spain; R. Dawson, My Reply to the Duchess of Atholl's 'Impressions of Spain' (Perth, 1936).

65 Archives of the Archdiocese of Glasgow, CU 12.

${ }^{66}$ Ball, 'The Politics of Appeasement', p. 58. 
On 22 February 1938, after Anthony Eden's resignation as foreign secretary, the duchess of Atholl abstained in the vote of confidence. ${ }^{67}$ In April 1938, the duchess resigned the government whip 'on account of the failure of the Government to take adequate steps to secure the withdrawal of Italian troops from Spain before the signature of the Italian pact, or to take action with other Powers to safeguard the peace in Central Europe and on the shores of the North Sea' ${ }^{68}$ Neville Chamberlain replied to her: 'I am satisfied that the interests of fair play have not suffered through the policy of non-intervention in Spain'. ${ }^{69}$ This was a decision which placed her outside the party. Her position was further weakened when, on 15 May, she spoke at a large rally of the International Peace Campaign in support of 'Arms for Spain' in Kelvin Hall, Glasgow. This rally, attended by four thousand people and chaired by Alan Boase, Professor of French at Glasgow University, concluded with the singing of the Internationale. Such details were reported by pro-Franco sympathiser Helen H. Strachan to Colonel Dawson as evidence of 'the great harm that is being done by your MP'.$^{70}$ On 27 May, the executive council of the Association voted overwhelmingly not to re-adopt the duchess at the next general election. ${ }^{71}$

On 27 September 1938, at the height of the Munich crisis, Saroléa wrote to Lady Maxwell-Scott: 'The future is very dark. It is almost fantastic to think that at the bidding of international Jews and Bolshevism, Europe is going to be driven to war in defence of a Czechoslovakia which has ceased to exist and which no French or British Army can possibly save'. ${ }^{72}$ For Saroléa, as for the vast majority of political opinion, relinquishing the Sudetenland to Germany was the only means by which European peace could be guaranteed, and the world saved from a hideous catastrophe.

The duchess's outspoken views on the 'shameful surrender' of Munich, issued in a leaflet on 7 November, did nothing to permit the reversal of the Association's decision, which was confirmed at the AGM. The duke of Atholl resigned from the presidency of the Association, and, on 24 November, his wife announced that she had also resigned and would fight the Kinross and West Perthshire by-election as an Independent: 'this is supremely a moment in which country must come before party'. ${ }^{73}$ In order to provoke a by-election, she applied for the Chiltern Hundreds, and on 1 December the writ was moved in the House of Commons. The local Liberal candidate, Coll MacDonald, who had polled a creditable ten thousand votes in 1935, reluctantly agreed to step aside to avoid splitting the anti-Government vote. ${ }^{74}$ On 17 November 1938, the spectacular victory of an

67 Ball, 'The Politics of Appeasement', p. 62.

68 The Scotsman, 29 Apr. 1938.

69 BCA, Duchess of Atholl Papers, 22/18.

${ }^{70}$ BCA, Duchess of Atholl Papers, 22/22.

71 Ball, 'The Politics of Appeasement', pp. 65-6.

72 EUL, Saroléa Collection, 64.

73 The Scotsman, 25 Nov. 1938.

${ }^{74}$ Ball, 'The Politics of Appeasement', pp. 69-70. 
Independent in the Bridgewater by-election seemed to show the potency of a 'popular front' electoral strategy. But there were limits to the breadth of the front and the 'redness' of the duchess. Certainly, on 28 November, the Soviet ambassador to London, Ivan Maisky, sent a message of goodwill: 'Congratulations on your courage in applying for the Chiltern Hundreds! I hope very much that such a determined and straightforward attitude will reap the victory it so richly deserves' ${ }^{75}$ At the same time, the duchess declined the Communist offer of support: 'I have no sympathy with the principles of the Communist Party'. The Unionist candidate, William McNair Snadden, a prominent breeder of pedigree Shorthorn cattle, robustly defended the foreign policy of Neville Chamberlain: 'The peoples of the world want peace. After Munich a universal sigh and prayer of thankfulness rose. The policy of $\mathrm{Mr}$ Chamberlain may take years to bear fruit, but some time the effort must be made, and now, when the minds of men, having glimpsed the awful horrors of war, are receptive to the idea, is the time to plant the seed of collaboration, and to hope that as the years pass it will grow into a fine flowering plant of lasting peace in Europe'. ${ }^{76}$

It was with the Kinross and West Perthshire by-election that the Spanish Civil War seemed to be transposed to Perthshire and some members of the Scottish aristocracy. Lady Maxwell-Scott was aware of the weakness of her forces elsewhere in Scotland. In late October, she wrote to Saroléa:

In Glasgow it has been a terrible struggle for, except for the Catholics, there is no support; on the contrary, a very well organised opposition which does not stop at violence. We were lucky last night, on the Rectorship platform, to have only celluloid balls and lumps of sugar thrown at us, as we expected tomatoes at least! ${ }^{77}$

Nevertheless, the struggle continued. Saroléa's counterblast, Daylight on Spain, completed in August, was guaranteed against loss by the marquis of Bute. ${ }^{78}$ To rival the Penguin cheap edition, it was published in Hutchinson's sixpenny series. Hutchinson had rejected the title, Searchlight on a Duchess, as 'offensive', while the initial title, A Scottish Duchess lost in the Jungle of Spain, was probably not snappy enough. ${ }^{79}$ The cover proclaimed: 'One of the greatest authorities on Spain gives a complete and crushing answer to the statements and views of the Duchess of Atholl'. ${ }^{80}$ This denunciation of a 'Comintern conspiration' was graced by an introduction by the comte de Saint-Aulaire, former French ambassador to London and Madrid and supporter of the far right Croix de Feu. Saint-Aulaire wrote of the conflict:

75 BCA, Duchess of Atholl Papers, 22/31.

76 The Scotsman, 8 Dec. 1938.

77 EUL, Saroléa Collection, 64

78 EUL, Saroléa Collection, 86, Saroléa to Lord Phillimore, 11 Jul. 1939.

79 EUL, Saroléa Collection, 86, unknown to Saroléa, 12 Nov. 1938.

80 Saroléa, Daylight on Spain (London, 1938). 
It is a gigantic duel in which, under the Sign of the Cross and the Spanish colours on the one side, and the Sign of the Sickle and the Hammer on the other, Order and Anarchy, Humanity and Barbarism, Good and Evil, Christ and Antichrist, are brought face to face. ${ }^{81}$

The retired diplomat expressed alarm at the 'epidemic' of aristocrats like the duchess of Atholl converting to the cause of the 'reds', while praising Saroléa's book as 'an excellent preservative from this strange disease'. ${ }^{22}$ For Saint-Aulaire, the professor was not just a great scholar and philosopher, but an 'apostle'. ${ }^{83}$

In Daylight on Spain, Saroléa endeavoured to subject the facts and conclusions of Atholl's book to 'the generally accepted tests of historical criticism and to the more acid tests of plain common sense and political realities'. ${ }^{84} \mathrm{He}$ concluded that her Conservative flag merely covered Bolshevik merchandise and argued that the former enemy of the reds had become their ally, a useful 'decoy duck'. Sarolea suggested that the triumph of the Spanish Republic that Atholl defended and misrepresented would be one further step by the 'Revolutionary Demagogue' towards its ideal of oriental despotism. On the deadly menace of communism, Saroléa concluded with typically apocalyptic verve: 'there is no possible recovery from an insidious deadly poison, from persistent loss of blood, from the inoculation of a virulent microbe. Death may be slower, but it is absolutely certain'. ${ }^{85}$

According to Sam Johnson, 'Saroléa's omissions from the text of Daylight on Spain are of far more interest to the historian" ${ }^{, 86}$. The most telling omission is explicit reference to the Jews. On reading the manuscript, Sir Walter MaxwellScott suggested that he "add "and Jewish" to Bolshevik influences [...] Jewish influence in Washington is very strong. Much stronger than the Bolshevik' ${ }^{87}$ However, Saroléa advised the Maxwell-Scotts of the political disadvantages of being publicly labelled an anti-semite: 'I do not think it would wise to add "Jewish" to Bolshevik [...] In our country it would be fatal even in conservative and much more in liberal and radical circles' ${ }^{88}$ Johnson remarks: 'such a label would immediately disqualify him from his self-appointed role as an impartial political commentator. It would also exclude him from the cosmopolitan circles he frequented. The Edinburgh Rabbi, for example, would have been none too impressed'. ${ }^{89}$ What is more, ever since the October Revolution, the equation

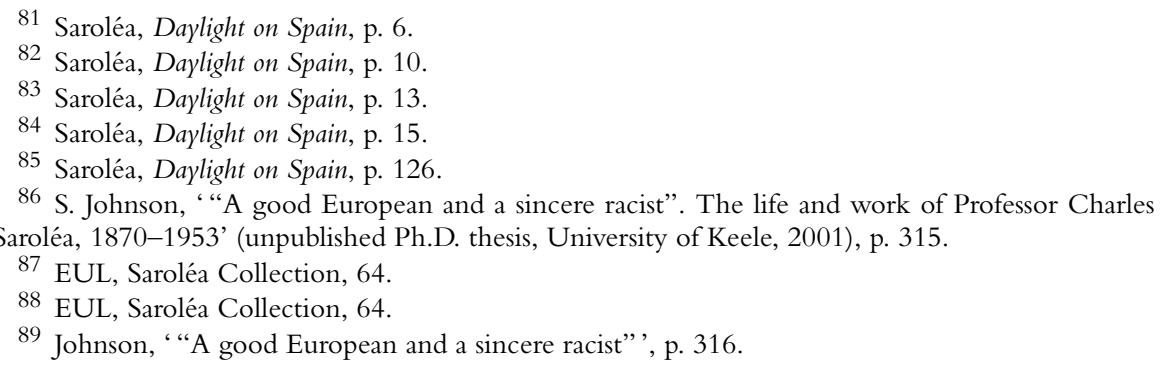


between 'Jewish' and 'Bolshevik' had become so entrenched in Sarolea's mindset that it did not need to be stated explicitly.

This polemical intervention was well received in influential circles. On 6 December 1938, the archbishop of Edinburgh wrote to Saroléa:

It is full of interest, and I can only hope that it may meet with an even wider circulation than the Duchess's pestilential book on Spain. It is amazing how effective the Russian propaganda has been in blinding even those who ought to know so much better as the real issue is at stake. I congratulate you on this production, and trust that it may do much to avert the very real danger which threatens this country at the moment through Communist propaganda. ${ }^{90}$

On 15 December 1938, the duke of Alba told Saroléa: 'Its issue in such a cheap form should go far to neutralise the damage done by the Duchess of Atholl's effusion, though I fear it is always more difficult to catch up with a lie than to start one!'. ${ }^{91}$ That said, if the compliments of Franco's representative to London were flattering, the propaganda importance of Saroléa's intervention should not be exaggerated: there is no mention of Daylight on Spain, for example, in the diplomatic archives of the Spanish Republic.

Despite international interest in the Kinross and West Perthshire by-election, it was, according to The Scotsman, a rather low-key campaign:

There appears to be little danger of the electoral waters rising in common with the turbulent waters of the Tay and the Tummel [...] Election addresses and leaflets are doubtless providing solid reading for the long evenings in remote cottages and elsewhere, but, apart from notices posted about meetings, there is an almost entire absence of flamboyant bills which might jar upon the senses of those who like the rural scene unspoiled by glaring displays. An emphatic and unfamiliar tone has been struck for the Duchess of Atholl, however, by loud speaker vans. The glens have been echoing for a few days with the booming voices of the Lloyd Georgian Council of Action. ${ }^{92}$

It became clear that McNair Snadden was a formidable opponent. His campaign was buttressed by the logistical help of Scottish Central Office and the oratorical support of a flood of National Government MPs. It was also helped by the influence exerted by sympathetic lairds on their tenants, notifying them, for example, of an abatement of rent during the campaign. ${ }^{93}$ In contrast, the duchess's supporters were enthusiastic but lacking in practical experience; meetings were badly advertised and on polling day cars were lacking. What's

90 EUL, Saroléa Collection, 61.

91 EUL, Saroléa Collection, 61.

92 The Scotsman, 17 Dec. 1938.

93 Ball, 'The Politics of Appeasement', pp. 78-9. 
more, her campaign spent too much effort on the villages and not enough on the towns in the more populous south of the constituency: for example, the duchess did not speak at all in Dunblane. ${ }^{94}$ This indicated how much ducal influence was limited to the highland region nearer to Blair Atholl, and even there it was waning. At the meetings themselves, the duchess's charisma showed its own limits. Her otherwise sympathetic biographer Sheila Hetherington writes: 'Her voice was a rather monotonous drone, her speeches were too long and her appearance was uninteresting. ${ }^{95}$ The campaign also showed the duchess's isolation from the Conservative Party, which was increased by her decision not to stand as an 'Independent Conservative'. What's more, as Stuart Ball points out, she made a tactical error by devoting much of her attention to the Spanish issue: "it ensured the continuance of Roman catholic antagonism. Although the "scarlet woman" of Rome was a more deeply entrenched bogey than the "red duchess" of Atholl, the latter did not benefit from any Protestant backlash'. ${ }^{96}$ A son of the manse, McNair Snadden was palatable to presbyterian and catholic alike.

Nevertheless, it was still a surprise that on 21 December, 'a day of wild winter weather and heavy snow', McNair Snadden narrowly prevailed over the duchess of Atholl, by a majority of 1,300 votes. ${ }^{97}$ The crucial element in his success had been the 'solidarity' of the Conservative vote, which had held up better on a lower turnout. The defeated duchess thanked those 'who share my views, and long to see this country return to a foreign policy more consistent with our great traditions and our immense responsibilities'. McNair Snadden told one reporter: 'This is not a victory for me; it is a tremendous victory for $\mathrm{Mr}$ Chamberlain; against an established member and all the natural prejudice in favour of a well-known Perthshire personality, the cause of Mr Chamberlain has triumphed in an almost overwhelming manner. ${ }^{98}$ Indeed, as The Scotsman reporter pointed out, despite the 'popular front' triumph at Bridgewater, in the eight by-elections since the Munich Agreement, the total number of votes cast for the Government candidates had been 200,000, against 180,000 polled by Opposition candidates. According to Ball, both Conservative leaders and voters 'were fed up with the Spanish wrangle, and either did not understand the issue or feared that the duchess's policy would lead to British entanglement and defeat the hope of localising the conflict'. ${ }^{99}$ During the campaign, a Crieff working-class woman had told Mass Observation: 'I am voting for Mr Chamberlain, he saved war'. ${ }^{100}$

94 Ball, 'The Politics of Appeasement', p. 72.

95 S. J. Hetherington, Katharine Atholl 1874-1960: Against the Tide (Aberdeen, 1989), p. 215.

96 Ball, 'The Politics of Appeasement', p. 73.

97 Hetherington, Katharine Atholl, p. xvi.

98 The Scotsman, 23 Dec. 1938.

99 Ball, 'The Politics of Appeasement', p. 83.

100 Sussex University Library, Mass Observation MSS, Interviews at Crieff, Box 2, File D, cited in Ball, 'The Politics of Appeasement', p. 83. 
On 22 December 1938, Saroléa could therefore crow to Lord Phillimore:

We have done it and the Red Duchess has been ignominiously beaten. I must confess, until the last moment, my only hope was that we might reduce her majority. A displacement of 650 votes in her favour would have given her the Seat. We may flatter ourselves that it is our little book which has made all the difference and influenced, in our favour, those 650 jurymen good and true. ${ }^{101}$

After all, in the week of the by-election, The Glasgow Observer, under the title 'The Battle of the Books', had declared: 'Professor's Daylight dims Duchess's Searchlight'. ${ }^{102}$ The following day, Lady Maxwell-Scott expressed both joy and wariness: 'Never in our wildest dreams could we have expected such a result in such a feudal part of Scotland. [...] But her energy has become diabolical now, and she has no more idea of giving up fighting for the Reds of the whole world than Stalin has'. ${ }^{103}$ A reply from Saroléa reasserted the importance of his intervention, though also indicated other, perhaps more mundane, factors explaining the duchess's defeat:

2,000 copies were sent to Scotland have done much good. In fact, they have been the cause of the Red Duchess losing many votes. It was indeed a splendid victory. [...] The opinion of the public was also very clearly shown in the fact that in spite of her territorial influence, she could only muster 60 cars against the 500 for Snadden. ${ }^{104}$

On 3 January 1939, the duchess was at least consoled by Pablo de Azcarate, the Republic's ambassador to London:

On my return from a short visit to Barcelona, I hasten to offer you the expression of my heartfelt sympathy, and tell you of the deep regret with which the Spanish people learned the result of the West Perthshire by-election. We must never forget, however, that the noblest aspect of the struggle is the risk of losing. ${ }^{105}$

The success of Daylight on Spain continued to gain momentum. On 11 January 1939, Alex McGregor junior wrote to Saroléa: 'I understand the book is going very well in Catholic circles. I sent copies to the Catholic Press and it has received very favourable reviews'. ${ }^{106}$ A week later, the director of the Institute for the Study of the Jewish Question wrote from Berlin: 'You are a true friend of ours in

101 EUL, Saroléa Collection, 86.

102 Glasgow Observer, 23 Dec. 1938.

103 EUL, Saroléa Collection, 64

104 EUL, Saroléa Collection, 64.

105 BCA, Duchess of Atholl Papers, 22/31.

106 EUL, Saroléa Collection, 86. 
the struggle against Jewish insolence and bolshevic imperialism'. ${ }^{107}$ The following day, Saroléa addressed a meeting in London of The Link, the Anglo-German fellowship, and declared: 'the Axis saved the world'. ${ }^{108}$ Though he opined to Lady Maxwell-Scott: 'I am waiting to see what further mischief our "Red Duchess" is preparing to do.'. 109

These were heady times. Barcelona fell on 26 January 1939, and sorry streams of Republican refugees made for the French frontier or the port of Valencia. On 2 February, at a celebratory dinner of the FNS, held in the Grosvenor restaurant, Glasgow, Saroléa proposed the first toast to Barcelona: 'The conquest of Barcelona has not only meant the liberation of thousands of misguided Catalonians, who received that liberation with such enthusiasm, but it has been a powerful blow to world Communism'. ${ }^{110}$ The Glasgow Observer reported:

A large portrait of General Franco, framed in the Nationalist colours, in the place of honour; the menu card printed in Spanish; the Nationalist colours everywhere; a musical programme consisting entirely of Spanish songs, and a regular chorus of 'Arriba Espana, viva Franco', - members of the Scottish branch of the Friends of National Spain were celebrating the liberation of Barcelona at a dinner in Glasgow last week. While the chief speaker, Professor Charles Saroléa, author of the book, Daylight on Spain, which helped to unseat the Duchess of Atholl in the West Perth by-election recently, was telling his audience that it was beginning to dawn on the British public that the Nationalists did represent the Spanish nation, a crowd of very ardent Valencia supporters gathered outside and loudly demanded arms for Spain. Several of the more foolhardy spirits rushed into the hotel, created pandemonium among a party of dancers who had nothing to do with the Spanish dinner, careered round the corridors shouting slogans and dodging the police. Six of them were taken into custody. ${ }^{111}$

Outside the restaurant, which held two hundred guests, a crowd of about two thousand demonstrated, waving red flags and shouting: 'Child Murderers Dine To-night! ${ }^{112}$. But it should be pointed out that opposition to Saroléa and the FNS was not limited to the Reds. From the outset of the Spanish Civil War, a vocal opponent of 'Franco the Baby-Killer' had been Alexander Ratcliffe, leader of the Scottish Protestant League, whose electoral popularity in Glasgow far outstripped that of the Communist Party. In The Vanguard, Ratcliffe lamented:

107 EUL, Saroléa Collection, 84.

108 The Scotsman, 18 Jan. 1939.

109 EUL, Saroléa Collection, 64.

110 Glasgow Herald, 3 Feb. 1939.

111 Glasgow Observer, 10 Feb. 1939.

112 Glasgow Herald, 3 Feb. 1939. 
We are not told that the King was 'toasted', or that the Union Jack was hoisted up. But we are told that the colours of National Spain draped the walls and tables and that the menu card was in Spanish, and that Spanish songs were sung. To our mind the fall of Barcelona and with it the evident success of Franco is a blow to world Protestantism. ${ }^{113}$

Saroléa boasted about the success of his book in reply to Alex McGregor: 'Only a few days ago a Clerk at one of the three bookstalls at the Waverley Station told me that the sales were going strong and that at his one Bookstall they had sold over 1,000 copies'. ${ }^{114}$ The ultimate accolade came on 14 March 1939, in a letter from the marques del Moral:

Mr Robert Sencourt, who was in Spain and who followed the troops into Barcelona at its capture, and has visited many of the towns and villages of Catalonia and Castille, told me that in his conversation with the people in the villages and towns he found a matter of enormous importance to them was the defeat of the Duchess of Atholl. People in Spain can understand a Duchess, but they cannot understand a Duchess who is Red! Her defeat was a momentous event in their opinion and created a great impression. ${ }^{115}$

Subsequent events seemed to vindicate Saroléa and his friends. Two weeks later, Madrid fell and then Valencia. Triumphant, the FNS renamed themselves the Friends of Spain.

Nevertheless, despite the confident declarations of McNair Snadden, Europe was indeed slipping rapidly towards another world war. The free city of Danzig was now in the sights of Hitler. On 19 June 1939, General Maxwell-Scott had no truck with any intervention against Nazi Germany:

If we have to fight with Russia we shall be fighting alongside the Reds and Pinks of the world, with the Jews and with the Grand Orient and with all the Anti-Gods. But what can you expect from a country in which Christianity is dying, in which easier divorce and abortion is on the increase, and where contraception is used more and more to stop an urgently needed increase of the population! ${ }^{116}$

Saroléa wrote to The Scotsman on the issue of Danzig, supporting 'peace'. ${ }^{117}$ His appeals seem to have fallen on deaf ears. On 22 June 1939, he informed C. E. Carroll, of the Anglo-German fellowship:

Nobody, so far, has taken my side except a Ukrainian nobleman. That is where the mischief lies. I had two enthusiastic letters from the Duke of Buccleuch

113 The Vanguard (March 1939), p. 1.

114 EUL, Saroléa Collection, 86.

115 EUL, Saroléa Collection, 86.

116 EUL, Saroléa Collection, 64.

117 Saroléa, 'Poland and Germany', The Scotsman, 14 Jun. 1939. 
and from the leader of the SNP, Mr Gibb, who informed me that they agree with every word I said. But why do these gentlemen who agree with me in private fail to express their agreement in public? ${ }^{118}$

Indeed, at an SNP conference in May 1939, Andrew Dewar Gibb, who was an avid collector of Saroléa's Scotsman letters, as well as maintaining close contact with Gerhard von Tevenar, a Nazi, Celtic scholar, and an agent for German intelligence ${ }^{119}$, had declared:

The people of this country are being stampeded into war. The press, the BBC, so called responsible ministers by their inflammatory utterances are all working up a will to war as though in a sacred cause. There is only a threat, actual or imaginary to the supremacy of British imperialism. We indeed as nationally minded Scotsmen may well condemn recent rapine and conquest. But it requires a fit of brass indeed for imperial England with her long record of rapacity and cunning to criticise the actions of any other country. ${ }^{120}$

Gibb's public silence on the Danzig issue notwithstanding, Saroléa told the SNP leader on 30 June:

Of course neither you, nor I, nor anybody can reveal the substantial truth. The driving forces behind our policy are, first, the Jews, which means France, Big Business and the Press, as well as the Cinema and the BBC. The second most powerful driving force is the Church, for this will be partly a Religious War. ${ }^{121}$

On 22 October 1939, nearly two months after the declaration of war, Gibb told Saroléa: 'I feel everyone among us who feels the pinch of the Communist threat, with the 3 great powers insanely weakening themselves, should strive to do all in his power to counter it. What service can we render?'122

The Nazi-Soviet Pact of August 1939 tore apart those anti-Fascists who had rallied to the Spanish Republican cause and the Communist Party, but also caused considerable confusion and soul-searching among pro-fascists. During this period, there were terse exchanges between Lady Maxwell-Scott and Professor Saroléa. Lady Maxwell-Scott's profoundly Catholic and Latin affinities led her to prefer the cause of Franco or Mussolini to that of the Godless 'Prussians' in Berlin. In the wake of the Molotov-Ribbentrop scandal, she declared: 'we want to add Stalin to

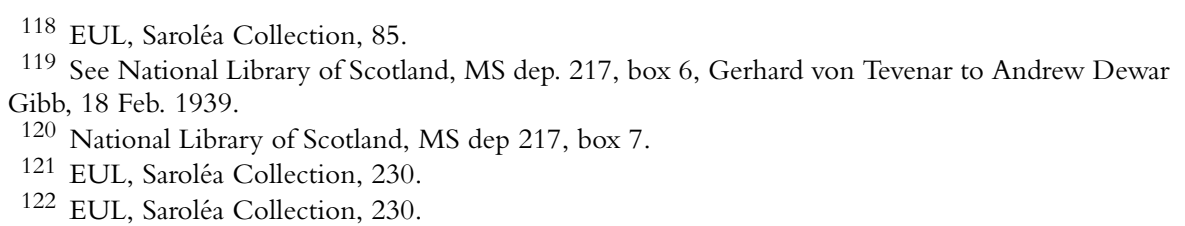


Hitler as the Enemy'. ${ }^{123}$ Maxwell-Scott denounced the invasion of Belgium and France and expressed her support for Charles de Gaulle's Free French. However, in early 1940 Maxwell-Scott and Saroléa were still united in their support of armed intervention in Finland against the invading Red Army. She told him: 'I have 60 women working for the Finns, knitting hard, and work-parties all up Yarrow and Ettrick are working for me too, so we send a steady stream to London every week'. ${ }^{24}$

As for the duchess of Atholl, it can be said that, in her remaining years, she would effectively move back towards her erstwhile friends, as a prominent member of the British League for European Freedom and opponent of Soviet control of Eastern Europe. ${ }^{125}$ As far as Spain is concerned, the Saroléa papers contain standard letters in 1943-5 from the duchess of Atholl, asking for donations to the National Joint Committee for Spanish Relief and Basque Children's Trust Ltd, accompanied by an annual report and financial statement. ${ }^{126}$ For example, in October 1945, she wrote: 'We are all hoping that the situation in Spain may make it possible for the Spanish refugees here and in France to return soon to their own Country and that the end of our responsibilities as the NJCSR, is at least in sight'. ${ }^{127}$ There are, however, no replies from Saroléa to the duchess or indications of money being donated to this humanitarian cause. Barely six years after the triumphant entry into Barcelona, there was little hope for the pro-Francoists. In late August 1944, her beloved Paris may have been liberated, but Lady MaxwellScott wrote to Saroléa: 'I weep with you over the Atheists, but as most of the world is with them in their firm determination to prepare the ground for the arrival of Anti-Christ and his Materialism, they ride the crest of the wave'. ${ }^{28}$

Indeed, the end of the Second World War was the high watermark of antifascism and the communist movement in Europe. Saroléa, suffering from the inevitable problems of advanced old age, withdrew from the public debates in which he had once been a constant participant. Certainly, he did not abandon anti-semitism, becoming a close friend of Admiral Sir Barry Domvile on the latter's release from internment. There is no mention of the Holocaust in his last writings, although he continued to obsess about bolshevism: on 1 January 1948, he noted that Stalin was 'the master dictator of the world' ${ }^{129}$ In 1946, Saroléa had made one last trip to the continent, visiting Belgium, Germany and France, but not Spain. However, he retained sympathies for a Franco regime which was very much persona non grata: Spain was politically and economically isolated and excluded from the United Nations. On 9 July 1946, Lord Phillimore wrote to

123 EUL, Saroléa Collection, 64.

124 EUL, Saroléa Collection, 64.

125 See Hetherington, Katharine Atholl, pp. 221-2.

126 EUL, Saroléa Collection, 139.

127 EUL, Saroléa Collection, 139.

128 EUL, Saroléa Collection, 64.

129 EUL, Saroléa Collection, 157. 
Saroléa: 'I regret to say that we find that there is more bitter opposition to the Franco regime today than there was even in the days of the Civil War'. ${ }^{130}$ Saroléa was also bitter in his reply, indicating the weight of the religious divide in his chosen home, as well as his own isolation:

I admit that propaganda for Spain in a Protestant country is a somewhat difficult proposition. [... ] I made a free gift of my little book to the Committee of the Friends of Spain. I made two costly and fatiguing journeys to Spain at my own expense. I succeeded in getting my friend Comte de Saint-Aulaire, a former Ambassador to Spain, to write an inspiring Introduction to the book, but I did not see a single article published in the London press on my book. Nor did I receive a single letter or postcard from Spain. ${ }^{131}$

He wrote thus to the press attaché of the Spanish Embassy:

Unfortunately Spain has been hidden away from us for so long behind the Iron Curtain of hostile propaganda that it is very difficult to see for one's self and even more difficult to make other people see the facts of the Spanish situation [...] It is obvious to me that Spain is the victim of a sinister political conspiracy whose wire-pullers are in Moscow as well as in Paris, London and Washington. ${ }^{132}$

On 28 November 1946, the Spanish ambassador in London cabled to Madrid that the Friends of Spain had been 'reorganised and rejuvenated'. ${ }^{133}$ There was no longer any place for the professor.

In fact, Franco's Spain would, with the Cold War, soon find a role in the western alliance against 'Godless Communism', welcoming US air bases as early as 1955, while becoming a popular destination for Scottish holidaymakers, both protestant and catholic. But Saroléa would not live to see these developments, dying on 11 March 1953, six days after Joseph Stalin. His obituary in The Times concentrated on his passion for languages and books, and skirted around his political affinities, although it also declared that in the final stages of his life, Saroléa 'found it difficult to adapt his thought to the new values created by the quickening tempo of the modern world'. ${ }^{134}$

On 5 May 1944, Saroléa had written to his good friend the duke of Argyll: 'I have tried to specialise in political prophecy for the last thirty years'. ${ }^{135}$ There was certainly a time at which the professor seemed to have the gift of insight

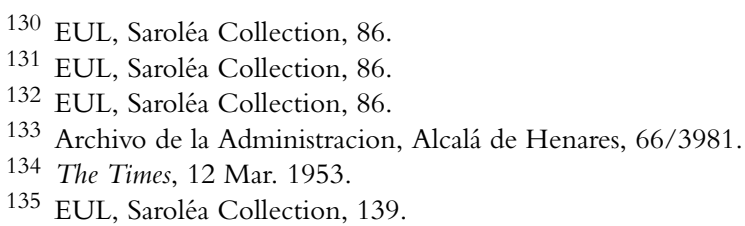


into geopolitical developments. In 1915, on the appearance of the US edition of The Anglo-German Problem, The New York Times hailed Saroléa as a 'seer' who had predicted with 'rare perspicacity' the Kaiser's aggression against Belgium, France and Britain. ${ }^{136}$ However, the professor's obsessive fear of the Bolshevik threat blinded him to both the aggressive character of fascism and the limits of Soviet influence. To this was added an exaggerated sense of his own importance. These faults illustrate themselves in his campaign against the 'red duchess', which, if in touch with pro-appeasement opinion, and buoyed by catholic sympathies, was of marginal impact. Sam Johnson rightly remarks: 'if there were individuals who were swayed by Saroléa's advice and knowledge, they were confined to the lower echelons of politics and international affairs. The prime example here is Lady Maxwell-Scott'. ${ }^{137}$ In the years following the 'battle of the books' over Spain, both the professor and the duchess would know, in different but related ways, the bitter taste of defeat.

136 'Dr Sarolea's Remarkable Forecast', New York Times, 18 Apr. 1915.

137 Johnson, "“A good European and a sincere racist”, p. 347. 